Journal homepage: www.aesacademy.org

\title{
Effect of sunlight and artificial light on micropropagation of potato (Solanum tuberosum L.) plantlets
}

\author{
S. Rehana ${ }^{1^{*}}$ (D) , F. Ahmed ${ }^{1}$, N. Zeba ${ }^{2}$, A. Husna ${ }^{2}$ and F. Hossain ${ }^{3}$ \\ ${ }^{1}$ Biotechnology and Genetic Engineering Discipline, Khulna University, Khulna 9208, BANGLADESH \\ ${ }^{2}$ Department of Genetics and Plant Breeding, Sher-E-Bangla Agricultural University, Agargaon, Dhaka 1207, BANGLADESH \\ ${ }^{3}$ Rural Development Academy, Bogra, BANGLADESH \\ "Corresponding author's E-mail: saydarehana@gmail.com
}

\section{ARTICLE HISTORY}

Received: 18 May 2018

Accepted: 30 May 2018

\section{Keywords}

Artificial light

Micro-propagation

Morphological responses

Potato plantlets

Sunlight

\section{ABSTRACT}

Fluorescent lamps (artificial light) and sunlight were used as lighting source in present study to identify feasibility of using sunlight in plant tissue culture laboratory. In vitro regenerated nodal segments of the cardinal variety of potato (Solanum tuberosum L.) were inoculated in MS medium without any growth regulator for shoot and root development. After 30 days of culture in an average temperature at $21.94 \pm 0.21^{\circ} \mathrm{C}$, relative humidity $39.35 \pm 0.75 \%$, various morphological responses i.e. plantlet height, diameter of plantlet, number of nodes per plantlet, inter node distance, number of leaves per plantlet, fresh and dry weight of plantlets, number of root, length of root, growth rate etc. were recorded. The average light intensity at sunlight and artificial treatment was observed at $4805.5 \pm 326.54$ lux and $3484 \pm 84.44$ lux, respectively. All the growth factors performed better result in sunlight treatment than those of artificial one except average number of nodes and leaves. The average height of plantlet at sunlight was $53.33 \pm 3.32 \mathrm{~mm}$ which was greater than that of artificial light $51.67 \pm 2.15 \mathrm{~mm}$. Fresh weight and dry weight are two important morphological factors for plantlet and in case of fresh weight that was always greater $0.49 \pm 0.097$ in sunlighted plantlet and $0.21 \pm 0.026$ in artificial one. In case of dry weight the average weight $0.08 \pm 0.016$ was greater in sunlighted plantlet than that of $0.03 \pm 0.004$ in artificial one. Number of roots, root length and growth rate of the plantlets observed higher in sunlighted plantlets compared to artificial light. Moreover, the sunlighted plantlets were healthier, vigorous and strong which helped plants to establish in net house easily. Considering the cost of electricity consumption, from a laboratory area of $20.47 \mathrm{~m}^{2}$ BD Taka $63 \%$ could be saved in each month by using sunlight. As low cost options of energy saving in tissue culture laboratory using sunlight would be feasible and environmentally friendly technology for commercial point of view in Bangladesh.

(C)2018 Agriculture and Environmental Science Academy

Citation of this article: Rehana, S., Ahmed, F., Zeba, N., Husna A. and Hossain, F. (2018). Effect of sunlight and artificial light on micropropagation of potato (Solanum tuberosum L.) plantlets . Archives of Agriculture and Environmental Science, 3(2): 151-156, https://dx.doi.org/10.26832/24566632.2018.030208

\section{INTRODUCTION}

Following rice, wheat and maize (Moeinil et al., 2011) potato (Solanum tuberosum L.) places the world's number one non-grain food commodity and fourth largest food crop. In Bangladesh, considering area and production potato is the third largest vegetable crop next to rice, and wheat with an average yield of $19.64 \mathrm{t} \mathrm{ha}^{-1}$ (BBS, 2018). Due to an economically important crop different methods of rapid multiplication of potato are used in various laboratories and different countries (Jones, 1988). In vitro propagation of potato is influenced by various factors including growth regulators, cultivar, light quality, photoperiod and temperature. The effects of growth regulators on microtuber induction have been extensively studied by many researchers. Hussey and Stacey (1984), Estrada et al. (1986), Simko (1993), Tugrul and Samanci (2001) used different growth regulators for in vitro induction of microtubers. Several physiological studies such as hormonal composition and concentration of phytohormone, ratio of photoperiod, composition and concentration of nutrients in the media etc. have shown that in vitro 
tuberization of potato is controlled by different factors (Coleman et al., 2001; Zobayed et al., 2001; El-Sawy et al., 2007; Anoop and Chauhan, 2009). However, few significant works have been reported on using the different sources of light on micro propagation of potato in vitro (Kereša et al., 2012).

Light plays an important role on growth and development of the in vitro culture plants. Among various physical micro environmental factors which influence photosynthesis of in vitro cultured plants, high sucrose and salt containing media, low light level and carbon dioxide concentration in the culture vessel are some of the important limiting factors (Fujiwara and Kozai, 1995). Beside photosynthesis, light, both quantity and quality, is involved in several processes of plant development such as photomorphogenensis and photoperiodism and the expression of many genes is affected by light (Hopkins, 1999). As the importance of light in the plant growth, artificial light sources are used in plant tissue culture laboratory to provide all the light a plant needs. Lighting costs account for $65 \%$ of total electricity bill (Standaet de Metsenaere, 1991) and are one of the highest non labor cost in a tissue culture laboratory (Dooley, 1991). Moreover, artificial lighting generates heat that has to be dissipated by cooling and air conditioning further adding to the electrical load. The cool fluorescent lights used for illumination provide minimal energy required for photosynthesis. As a result, in vitro plants adapt to low-light intensity, and have a reduced growth rate (Ahloowalia and Savangikar, 2002). Natural light used to illuminate potato tissue cultures in India and Cuba produced acceptable cultures and considerable saving of energy (Alix et al., 2001). It has observed that plants can grow vigorously in the absence of sugar if provided with proper ventilation system coupled with high photosynthetic photon flux (PPF) of 100-150 $\mu \mathrm{mol} \mathrm{m}^{-2} \mathrm{~s}^{-1}$ and lower percentage of relative humidity inside the culture vessel (Chun and Kozai, 2001) that can be maintained by sun light.

Due to lack of required electricity production and increasing demand of seed potato through micropropagation using sunlight instead of artificial light could be the new tissue culture tool for Bangladesh. In this study the potential and advantages of using sunlight instead of artificial light for potato micropropagation and its effects on different morphogenic characters of the plantlets were investigated to achieve the objectives such as the growth factors (length and diameter of plantlet, length of root, no of nodes etc), feasibility study and analyze the cost of electricity consumption in two lighting conditions in plant tissue culture laboratory.

\section{MATERIALS AND METHODS}

The research work has been carried out at the plant tissue culture laboratory, Rural Development Academy (RDA), Bogra, Bangladesh to observe different morphogenic characters i.e. length and diameter of plantlet, number of nodes per plantlet, number of leaves per plantlet, inter node distance between two nodes, fresh and dry weight of plantlets, number and length of root, growth rate of shoot etc. The explants collected from in vitro cultured potato variety Cardinal, developed through meristems culture in vitro, were used as the initial planting material. MS (Murashige and Skoog, 1962) medium without any growth regulator was used as basal medium. After collection of explants from cultured vessels, carefully and aseptically each plantlet was cut into pieces about $2 \mathrm{~cm}$ by surgical blade bearing one node and one leaf in each explant and placed on the sterilized glass. After preparing sufficient amount of explants for one bottle, they were inoculated into the glass bottle containing about $30 \mathrm{ml}$ of MS (Murashige and Skoog, 1962) medium without any growth regulator. They were then kept in growth room in two types of culture conditions in respect to source of light. In case of sunlight the average light intensity was $4805.5 \pm 326.54$ lux and photoperiod time 16 hours ( 10 hour day light and 6 hour artificial light). On the other hand in artificial light condition

average light intensity was $3484.23 \pm 84.44$ lux and photoperiod time 16 hours. The temperature was maintained at $21.94 \pm 0.021^{\circ} \mathrm{C}$ and relative humidity at $39.35 \pm 0.75 \%$ in the culture room. Culture bottles were arranged in the same distance in culture rack so that they were exposed to uniform light environment. The experiment was conducted in two treatments, in three replications and for each treatment five bottles with four plantlets were taken per replication. Plant growth was observed after 30 days of culture. Data were analyzed by using SPSS software.

Cost analysis of light intensity

Cost analysis was done by using the following formula: (Theraja and Theraja, 2005).

$$
\begin{array}{cc}
\mathrm{E}=\text { Illuminance }\left(\mathrm{Im} / \mathrm{m}^{2}\right) \text { or (lux) } & \\
\text { or, } \varphi / \mathrm{A}=\mathrm{L} & \mathrm{A}=\text { Area, } \mathrm{m}^{2} \\
\text { or, } \varphi=\mathrm{LA} & \mathrm{L}=\text { light intensity, lux } \\
& \varphi=\text { flux, Im }
\end{array}
$$

$\mathrm{P}$ Lux light intensity comes from $=\mathrm{Q}$ watt

$\varphi$ Lux light intensity comes from $=\mathrm{Q} / \mathrm{PX} \varphi$ watt

$$
\left.=\mathrm{R} \text { watt (total watt or } \mathrm{W}_{\text {total }}\right)
$$

$\mathrm{R}$ watt $=\mathrm{W}_{\text {total }} \times 10^{-3} \mathrm{Xh}=\mathrm{Z}$ units $(\mathrm{Z}$ KWh$)$

where, $\mathrm{h}=$ hour per day

1 unit electricity cost $=Y$ taka

$\mathrm{Z}$ units electricity cost $=\mathrm{YXZ}$ taka $=\mathrm{T}$ taka

\section{RESULTS AND DISCUSSION}

\section{Growth parameters}

Plant height $(\mathrm{mm})$ and diameter $(\mathrm{mm})$

Maximum height of potato plantlet was observed at sunlight, 72 $\mathrm{mm}$ and minimum $35 \mathrm{~mm}$. The average height of plantlet at sunlight was $53.33 \pm 3.32 \mathrm{~mm}$ which is greater than that of artificial light, $51.67 \pm 2.15 \mathrm{~mm}$ (Table 1). From Table 1 it can be revealed that lowest, highest and average diameter of potato plantlet at sunlight was greater than that of artificial light. It may be due to the intermittent intensive flow of sunlight compared to artificial light with constant flow. Jao and Fang (2004) also showed that intermittent or pulse light promotes the growth of potato plantlet significantly compared to artificial one. By changing Red photon flux density ( $R$, peak wave length 630nm, ranges between 10 and $100 \mu \mathrm{mol} \mathrm{m} \mathrm{s}^{-2}$ ) and far-red photon flux density (FR, peak wave length 730nm, range 2-50 $\mu \mathrm{mol} \mathrm{m} \mathrm{m}^{-2} \mathrm{~s}^{-1}$.) Miyashita et al. (2005) showed that shoot length of potato increased with increasing FR/PPFD ratio when R/PPFD ratio was 0.1-0.5. Miyashita et al. (2005) also showed that Shoot length was greatest with R/PPFD ratio of 1.0.

From the above results it may concluded that in sunlight red light spectrum present more which may lead plantlet to be more vigorous or stronger. On the other hand in artificial light it presents in a specific volume which makes plantlets thinner with spindly shoot as red light is the most important fuel for driving photosynthesis and biomass production of plants.

Number of nodes and internodes distance of potato plantlet Though highest and lowest numbers of nodes of plantlet were same but average number of nodes at sunlight, $7.75 \pm 0.39$ was lower than that of artificial light, $8.33 \pm 0.36$ (Table 2). Hussey and Stacey (1984) reported longer nodal formation in cultures with continuous light. As artificial light flow was continuous and sunlight flow was discontinuous and nature dependent so day length of artificial light represent more than that of sunlight. Beside this average inter node distance at sunlighted plantlet was $7.21 \pm 0.80$ and in artificial light $6.53 \pm 0.44$. It might be another reason that numbers of nodes at sunlighted plantlet were less than those of artificial light. 
Number of leaves of potato plantlets

Maximum leaves number was observed at artificial light, 13. Each node of potato plant contains one leaf and in artificial light plantlets had more number of nodes (Table 1). Therefore average numbers of leaves, $9.42 \pm 0.47$ were also higher than that of sunlight $9.25 \pm 0.43$ (Table 3 ). It might be due to the cause of uncontrolled light intensity of sunlight compared to artificial light. This result showed no significant difference between average number of leaves of sunlighted and artificial lighted plantlets. In micropropagation of chrysanthemum Miler and Zalewska (2006) showed no significant influence of light colour on an average number of leaves per plantlet.

High light intensity substantially increased the total number of expanded leaves, dry matter, sugar content and nitrogen absorbed in Phalenopsis (Kubota, 1993).

Fresh and dry weight of potato plantlet

Fresh weight is very important morphological factor for plantlet and that was always greater in sunlighted plantlet than that of artificial one (Table 4). Because the plantlets at sunlight were more vigorous (diameter and height) than that of artificial one and on the other hand the fresh weight of sunlighted plantlets was higher than that of artificial light so dry weight was also higher. Nhut et al. (2003) showed the highest total fresh weight of banana plantlets obtained under $80 \%$ red $+20 \%$ blue LED and the value was equivalent to that under plant growth fluorescent lamps (PGF). As red light \% at sunlight has more so growth rate, fresh and dry weight of sunlighted plantlet were more than that of artificial one.

Number and length of root

Root number and length is an important factor for any plantlet before they are being transplanted in field because root helps plants to absorb necessary foods from soil. Considering root length of plantlet longer roots can collect food constitutes from long distance of soil. The root number and length were always higher at sunlight than that of artificial light (Table 5). The longer root length, $64 \mathrm{~mm}$ was observed at sunlight whereas at artificial light it was $29 \mathrm{~mm}$. The average root length at artificial light, $15.70 \pm 1.88 \mathrm{~mm}$ was significantly less than that of sun light, $44.42 \pm 4.42 \mathrm{~mm}$ (Table 5). In case of in vitro rooting of Faidherbia albida, Kwapata et al. (1999) showed that the number of roots per shoot increased significantly with increasing incubation of light intensity, and an optimum of 10 roots per shoot was obtained at $135 \mu$ moles $\mathrm{m}^{-2} \mathrm{~s}^{-1}$ light conditions. Kozai et al. (1997, 1999) and Jeong et al. (1995) also obtained the same result with an increased sun light intensity at least $150 \mu$ moles $\mathrm{m}^{-2} \mathrm{~s}^{-1}$ and could concluded that the plantlets did not require any acclimatization during post vitro establishment. Highest percentage of root was found in micropropagation of Alternanthera brasiliana. $\mathrm{L}$ when ultraviolet radiation was used which is present in Sun light (Silva et al., 2005). Wang and Hu (1985) also observed efficient rooting of micro tuber grown cutting of potato in high light intensity $\left(120 \mu\right.$ moles $\left.\mathrm{m}^{-2} \mathrm{~s}^{-1}\right)$ with a $12-\mathrm{h}$ photoperiod.

\section{Growth rate of shoot $\mathrm{mm} /$ day}

In commercial micropropagation of potato, growth rate is an important factor considering cost benefit. The growth rate of plantlet at sunlight was always more than that of artificial light (Table 6 and Figure 1). In case of strawberry, Nhut et al. (2003) showed that Plantlet growth rate was best at $70 \%$ red $+30 \%$ blue LEDs. The optimal light intensity was $60 \mathrm{~mol} \mathrm{~m}^{-2} \mathrm{~s}^{-1}$. Chlorophyll synthesis is stimulated by red light. Because the effect of red light showed some far-red reversibility in successive red and far-red light treatments. In addition to the effect of red light, a strong stimulation of chlorophyll synthesis by blue light was observed in green algae (Lopez and Neill, 1989). As red light presents at higher ratio so photosynthesis and growth rate was greater in sunlighted plantlets than to artificial light. Depending on the intensity and duration of light treatment Jo et al. (2008) showed that both light intensity and photoperiod independently affect growth of Alocasia amazonica. Kodym et al. (2001) observed good or better growth under natural light than in the controlled growth room, kept at $16-41^{\circ} \mathrm{C}$ at $750 \mu \mathrm{mol} \mathrm{m} \mathrm{s}^{-1}$, of in vitro grown plants of banana and potato. From the above discussion it was observed that morphological characters of sun lighted plantlets performed better than that of artificial one (Figure 1).

Cost analysis of light intensity at RDA plant tissue culture laboratory

Changing the method of illumination from artificial to natural light not only reduces electricity and capital costs, but also improves the plant quality. Expensive artificial lights can be replaced in several ways in different conditions. Countries like Cuba, Denmark, India and Vietnam are the milestone of using sunlight instead of artificial one in tissue culture or micropropagation (Beazas-Lopez, 1995). In Bangladesh, Rural Development Academy (RDA) Tissue Culture Laboratory is only practicing to use sunlight instead of artificial one as a physiological factor for micropropagation of potato plantlet. Generally, potato tissue culture needs 3000-4000 (average 3500) lux light intensity to maintain its morphological characters. RDA plant tissue culture laboratory growth room has an area of about $(10 \times 22)$ sq. feet i.e. $(3.048 \times 6.71) \mathrm{m}^{2}=20.47 \mathrm{~m}^{2}$. Therefore light intensity cost (sunlight and artificial light) has been calculated by using the following formula of Theraja and Theraja (2005).

$A=20.47 \mathrm{~m}^{2}(6.71 \times 3.05)$

$\Phi=\mathrm{LA}$

Light intensity, $\mathrm{L}=3500$ lux.

$=3500 \times 20.47$

$=71645 \mathrm{Lux} \quad \varphi=\mathrm{Lux}, \mathrm{Im}$

2580 Lux light intensity comes from $=36$ watt (energy pack) 71645 Lux light intensity comes from $=(36 / 2580) \times 71645$ watt = 999.70 watt (total watt or $\mathrm{W}_{\text {total }}$ )

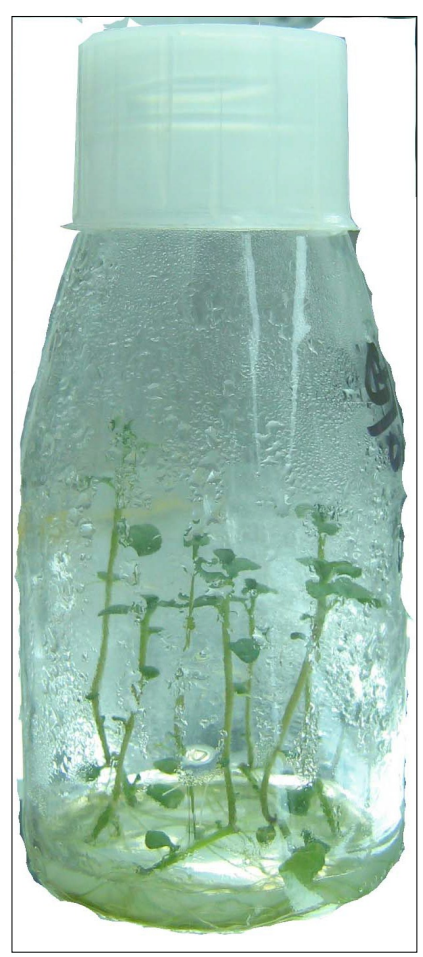

Sun lighted plantlets

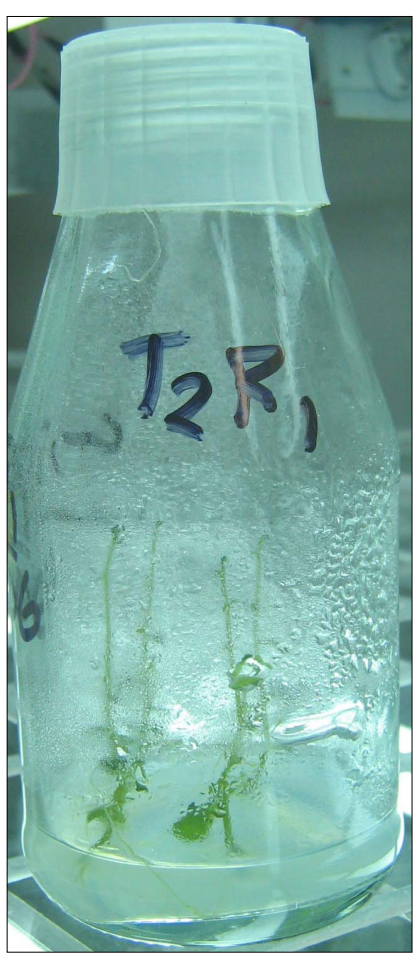

Artificial lighted plantlets
Figure 1. Comparative physiological appearance of plantlets under sun light and artificial light treatment (Photographs were taken after 30 days of culture). 
In case of using artificial light (considering 16 hour lighting period)

1 hour electricity consumption 999.70 watt

16 hours electricity consumption $=999.70 \times 16 \times 10^{-3} \mathrm{KWh}$

(units) $=16.00 \mathrm{KWh}$

1 day requires electricity $16.00 \mathrm{KWh} /$ Units

30 days requires electricity $=16 \times 30 \mathrm{KWh} /$ Units $=480$ Units

1 unit electricity cost is 6.0 taka

480 units electricity cost is $=6.0 \times 480$ taka $=2880$ taka

In case of using sunlight (considering 10 hour lighting period)

$\mathrm{A}=20.47 \mathrm{~m}^{2}(6.71 \times 3.05)$

$\Phi=\mathrm{LA} \quad$ Light intensity, $\mathrm{L}=4800$ lux.

$=4800 \times 20.47$

$=98256 \mathrm{Lux}$

$\varphi=\operatorname{Lux}, \operatorname{Im}$

2580 Lux light intensity comes from $=36$ watt (energy pack)

98256 Lux light intensity comes from $=(36 / 2580) \times 98256$ watt

$=1371$ watt (total watt or $\mathrm{W}_{\text {total }}$ )

1 hour electricity consumption 1371 watt

10 hours electricity consumption $=1371 \times 10 \times 10^{-3} \mathrm{KWh}$ (units)

$=13.71 \mathrm{KWh}$

1 day requires electricity $13.71 \mathrm{KWh} /$ Units
30 days requires electricity $=13.71 \times 30 \mathrm{KWh} /$ Units $=411.3$

Units

1 unit electricity cost is 6.0 taka

411.3 units electricity cost $=6.0 \times 411.3$ taka $=2467.8$ taka $\approx$ 2468.00

In case of using sunlight six hours artificial light is needed to complete the total lighting hour for in vitro condition of potato So six hour electricity cost is $2880 / 16 \times 6=$ Tk. 1080

For sixteen (16) hours total electric bill Bd. Taka 2880.00

For Six (6) hours total electric bill Bd. Taka 1080.00

Ten (10) hours total electric bill Bd. Taka 1800.00

I case of percentage of total electric bill would be saved $1800 \times$ $100 / 2880=62.5 \% \approx 63 \%$

Reduction in the cost of energy is essential to lower the production cost of micropropagated plants. A large part of the electrical energy in tissue culture is used for autoclaving, lighting of the growth room, air filtration in laminar-flow cabinets and air conditioning. In such a condition by using sunlight, RDA tissue culture laboratory is saving up to $63 \%$ of electricity consumption cost which reflects directly on micropropagation derived productions.

Table 1. Effect of sunlight and artificial light on vigourity of potato plantlet.

\begin{tabular}{|c|c|c|c|c|c|c|}
\hline \multirow[b]{2}{*}{ Treatment } & \multicolumn{3}{|c|}{ Plant height } & \multicolumn{3}{|c|}{ Plant diameter } \\
\hline & $\begin{array}{l}\text { Minimum } \\
(\mathrm{mm})\end{array}$ & $\begin{array}{l}\text { Maximum } \\
(\mathrm{mm})\end{array}$ & $\begin{array}{c}\text { Average }(\mathrm{mm}) \\
(x \pm S E)\end{array}$ & $\underset{(\mathrm{mm})}{\text { Minimum }}$ & $\begin{array}{l}\text { Maximum } \\
(\mathrm{mm})\end{array}$ & $\begin{array}{c}\text { Average }(\mathrm{mm}) \\
(x \pm \mathrm{SE})\end{array}$ \\
\hline $\begin{array}{l}\text { Sun light } \\
4805.5 \pm 326.54 \text { lux }\end{array}$ & 35 & 72 & $53.33 \pm 3.32$ & 0.85 & 1.5 & $1.03 \pm 0.054$ \\
\hline $\begin{array}{l}\text { Artificial light } \\
3484.23 \pm 84.44 \text { lux }\end{array}$ & 36 & 63 & $51.67 \pm 2.15$ & 0.53 & 1.07 & $0.75 \pm 0.041$ \\
\hline
\end{tabular}

Table 2. Effect of sun light and artificial light on node number and node distance of potato plantlets.

\begin{tabular}{lcccccc}
\hline \multirow{2}{*}{ Treatment } & \multicolumn{3}{c}{ Number of nodes } & \multicolumn{3}{c}{ Inter nodes distance } \\
\cline { 2 - 7 } & Minimum & Maximum & Average $(\mathbf{x} \pm \mathrm{SE})$ & $\begin{array}{c}\text { Minimum } \\
(\mathrm{mm})\end{array}$ & $\begin{array}{c}\text { Maximum } \\
(\mathbf{m m})\end{array}$ & $\begin{array}{c}\text { Average } \\
(\mathbf{x} \pm \mathrm{SE})\end{array}$ \\
\hline Sun light & 6 & 10 & $7.75 \pm 0.39$ & 4.67 & 14.33 & $7.21 \pm 0.80$ \\
Artificial light & 6 & 10 & $8.33 \pm 0.36$ & 3.67 & 9.67 & $6.53 \pm 0.44$ \\
\hline
\end{tabular}

Table 3. Effect of sun light and artificial light on the number of leaves of potato plantlets.

\begin{tabular}{lccc}
\hline \multirow{2}{*}{ Treatment } & \multicolumn{3}{c}{ Number of leaves } \\
\cline { 2 - 4 } & Minimum & Maximum & Average $(\mathbf{x} \pm$ SE) \\
\hline Sun light & 7 & 12 & $9.25 \pm 0.43$ \\
Artificial light & 7 & 13 & $9.42 \pm 0.47$ \\
\hline
\end{tabular}

Table 4. Effect of sun light and artificial light on the fresh and dry weight of potato plantlets.

\begin{tabular}{lcccccc}
\hline & \multicolumn{3}{c}{ Fresh weight } & & Dry weight \\
\cline { 2 - 7 } Treatment & $\begin{array}{c}\text { Minimum } \\
(\mathrm{g})\end{array}$ & $\begin{array}{c}\text { Maximum } \\
(\mathrm{g})\end{array}$ & $\begin{array}{c}\text { Average }(\mathrm{g}) \\
(\mathrm{x} \pm \mathrm{SE})\end{array}$ & $\begin{array}{c}\text { Minimum } \\
(\mathrm{g})\end{array}$ & $\begin{array}{c}\text { Maximum } \\
(\mathrm{g})\end{array}$ & $\begin{array}{c}\text { Average }(\mathrm{g}) \\
(\mathrm{x} \pm \mathrm{SE})\end{array}$ \\
\hline Sun light & 0.31 & 0.64 & $0.49 \pm 0.097$ & 0.06 & 0.11 & $0.08 \pm 0.016$ \\
Artificial light & 0.19 & 0.27 & $0.21 \pm 0.026$ & 0.03 & 0.04 & $0.03 \pm 0.004$ \\
\hline
\end{tabular}

Table 5. Effect of sun light and artificial light on number and length of root of potato plantlets.

\begin{tabular}{lcccccc}
\hline & \multicolumn{3}{c}{ Number of roots of plantlet } & \multicolumn{3}{c}{ Length of root per plantlet } \\
\cline { 2 - 7 } Treatment & Minimum & Maximum & $\begin{array}{c}\text { Average } \\
(\mathbf{x} \pm \mathrm{SE})\end{array}$ & $\begin{array}{c}\text { Minimum } \\
(\mathbf{m m})\end{array}$ & $\begin{array}{c}\text { Maximum } \\
(\mathrm{mm})\end{array}$ & $\begin{array}{c}\text { Average (mm) } \\
(\mathbf{x} \pm \mathrm{SE})\end{array}$ \\
\hline Sun light & 5 & 12 & $7.58 \pm 0.62$ & 10.67 & 64 & $44.42 \pm 4.42$ \\
Artificial light & 2 & 10 & $6.50 \pm 0.68$ & 5.67 & 29 & $15.70 \pm 1.88$ \\
\hline
\end{tabular}

Table 6. Effect of sun light and artificial light on growth rate of shoot.

\begin{tabular}{lccc}
\hline \multirow{2}{*}{ Treatment } & \multicolumn{3}{c}{ Growth rate of shoot } \\
\cline { 2 - 4 } & Minimum $(\mathrm{mm})$ & Maximum $(\mathrm{mm})$ & Average $(\mathbf{x} \pm$ SE)mm \\
\hline Sun light & 1.17 & 2.40 & $1.78 \pm 0.11$ \\
Artificial light & 1.20 & 2.10 & $1.72 \pm 0.072$ \\
\hline
\end{tabular}




\section{Conclusion}

The present study was conducted to identify the feasibility of using sun light instead of artificial one as a source of light intensity in micropropagation of potato plantlets (S. tuberosum). Three physiological factors such as light intensity, relative humidity and temperature were continuously observed and recorded for three times per day. Relative humidity in the growth chamber was average $39.35 \pm 0.75 \%$, minimum $32.47 \%$ and maximum $55.77 \%$. The light intensity at sun light treatment was fluctuated (average 4805.5 \pm 326.54 , minimum 1886.67, maximum 8725 lux) and at artificial light treatment was average $3484 \pm 84.44$ lux. The temperature was maintained at $21.94 \pm 0.21$ by air cooler. After 30 days of inoculation different types of growth factors were measured. Except average number of nodes and leaves all growth factors (average) at sun light treatment were more than that of artificial light. The growth factors like length of plantlet $53.33 \pm 3.32 \mathrm{~mm}, 51.67 \pm 2.15 \mathrm{~mm}$; diameter of plantlet $1.03 \pm 0.054 \mathrm{~mm}, 0.75 \pm 0.041 \mathrm{~mm}$; inter nodes distance7.21 $\pm 0.80 \mathrm{~mm}, 6.53 \pm 0.04 \mathrm{~mm}$; fresh wt $0.49 \pm 0.097 \mathrm{gm}, 0.21 \pm 0.026 \mathrm{gm} ;$ dry wt.08 $\pm 0.016 \mathrm{gm}$, $0.034 \pm 0.004 \mathrm{gm}$; number of root $7.58 \pm 0.62,6.5 \pm 0.68$; large root length $54.50 \pm 5.53 \mathrm{~mm}, 19.67 \pm 2.03 \mathrm{~mm}$; growth rate $1.78 \pm 0.11, \quad 1.72 \pm 0.072 \mathrm{~mm}$; nodes number $7.75 \pm 0.39$, $8.33 \pm 0.36$; number of leave $9.25 \pm 0.43,9.42 \pm 0.47$ at sun light and artificial light treatment, respectively. It can be concluded that S. tuberosum nodal segments carry a high potential for shoot and root formation on a simple culture medium without any growth regulator at sun light as a source of light intensity instead of artificial one (fluorescent). For mass scale plantlet propagation in Bangladesh, tissue culture laboratory could be developed where 10 hours /day sunlight would be used while an average of $63 \%$ BDT could be saved from a $20.47 \mathrm{~m}^{2}$ laboratory area. The use of sun light in plant tissue culture laboratory would be a new tool for Bangladesh in future.

\section{ACKNOWLEDGEMENT}

The authors desire to acknowledge Plant tissue culture laboratory of Rural Development academy (RDA) Bogra for using their area as well as lab facilities to accomplish this research work

Open Access: This is open access article distributed under the terms of the Creative Commons Attribution License, which permits unrestricted use, distribution, and reproduction in any medium, provided the original author(s) and the source are credited.

\section{REFERENCES}

Ahloowalia, B.S. and Savangikar, V.A. (2002). Physical components of tissue culture technology, low cost options for tissue culture technology in developing countries. In: Proceedings of a technical meeting organized by the joint FAO/IAEA division of nuclear techniques in food and agriculture. Vienna, Austria 26-30 August. Printed by IAEA in Austria, pp. 41-46.
Alix, M.J., Savvides, S., Blake, J., Herrmann, R. and Hornung, R. (2001). Effects of illumination source, culture ventilation and sucrose on potato (Solanum tuberosum) microtuber production under short days. Annals of Applied Biology, 139 (2):175-187, https://doi.org/10.1111/j.1744-7348. 2001. tb00394.x

Anoop, B. and Chauhan, J.S. (2009). Effect of growth regulators on meristem-tip development and in vitro multiplication of potato cultivar 'KufriHimalini'. Nature and Science, 7(9): 31-34, http://sciencepub.net/nature /0709/06_1027_ Anoop_Badoni_ns0709.pdf

BBS (2018). 45 Years Agriculture Statistics of major crops (Aus, Amon, Boro, Jute, Potato \& Wheat). Bangladesh Bureau of Statistics, http://bbs.portal.gov.bd/sites/default/files/files/ bbs.portal.gov.bdpage/16d38ef2_2163_4252_a28b_e65f6 Odab8a9/45\%20years\%20Major\%20Crops.pdf

Beazas-Lopez, P. (1995). Cubans enlist the sun in virus- free propagation, Cerescope: the FAO review no. 156 (vol. 27, no 6): 15-16.

Chun, C. and Kozai, T. (2001). A closed transplant production system, a hybrid of scaled-up micropropagation system and plant factory. Journal of Plant Biotechnology, 3(2): 59-66, http://210.101.116.28/W_files/kiss2/05801621_pv.pdf

Coleman, K.W., Danielle, J.D. and Colleman, S.E. (2001). Potato microtuber as research tools: A Review. American Journal of Potato Research, 78: 47-55, https://doi.org/10.1007/ BF02874824

Dooley, J.H. (1991). Influence of lighting spectra on plant tissue culture. Presented at an ASAE (American Society of Agricultural Engineers) meeting, Chicago, Illinois.

El-Sawy, A., Bekheet, S. and Aly, U.I. (2007). Morphological and molecular characterization of potato microtubers production on coumarin inducing medium. Journal of Agricultural Biology, 9(5): 675-680, http://agris.fao.org/agris-search/ search.do?recordID=PK2008000452

Fujiwara, K. and Kozai T. (1995). The physical microenvironment and its effects. In: Aitken-Christie J, Kozai T \& Smith MAL (eds) Automation and Environmental Control in Plant Tissue Culture, Kluwer Academic Publishers, Dordrecht, The Netherlands, pp. 319-369.

Hopkins, W. G. (1999). Introduction to Plant Physiology. 2nd ed. New York, NY: John Wiley \& Sons, Inc. pp. 512, https:// trove.nla.gov.au/work/8827904

Hussey, G. and Stacey, J.N. (1984). Factors affecting the formation of in vitro tubers of potato (Solanum tuberosum L.). Annals of Botany, 53(4): 565-578, http://www.jstor.org/ stable/42757416

Jao, R.C. and Fang, W. (2004). Effect of frequency and duty ratio on the growth of potato plantlets in vitro using light emitting diodes. Horticultural Science, 39 (2): 375-379, http:// hortsci.ashspublications.orgcontent/39/2/375.full.pdf+html

Jo, E.A., Tewari, R.K. and Hahn, E.J. (2008). Effect of photoperiod and light intensity on in vitro propagation of Alocasia amazonica. Plant Biotechnology Reports, 2 (3): 207-212, https://doi.org/10.1007/s11816-008-0063-6 
Jones, E.D. (1988). A current assessment of in vitro culture and other rapid multiplication methods in North America and Europe. American Potato Journal, 65(4): 209-220, https:// link.springer.com/article/10.1007/BF02854453

Jeong, B.R., Fujiwara, K. and Kozai, T. (1995). Environmental control and photoautotrophic micropropagation. Horticultural Review, 17: 123-170.

Kereša, S., Mihovilovi, A., Bari, M., Židovec, V. and Skelin, M. (2012). The micropropagation of chrysanthemums via axillary shoot proliferation and highly efficient plant regeneration by somatic embryogenesis. African Journal of Biotechnology,11(22): 6027-6033, http://www. academic journals. org/article article1380984793_Keresa\%20et\% 20al.pdf

Kodym, A., Hollenthoner, S. and Zapata-Arias, F.J. (2001). Cost reduction in the micropropagation of banana by using tubular skylights as source for natural lighting. In vitro Cellular and Developmental Biology, 37 (2): 237-242, https:// doi.org/10.1007/s11627-001-0042-x

Kozai, T., Kubota, C. and Jeong, B.R. (1997). Environmental control for the large-scale production of plants through in vitro techniques. Plant Cell, Tissue and Organ Culture, 51: 49-56, https://doi.org/10.1023/A:1005809518371

Kozai T., Nguyen Q.T. and Chun C. (1999) Environmental Control in Photo Autotrophic Micropropagation. In: Altman A., Ziv M., Izhar S. (eds) Plant Biotechnology and In Vitro Biology in the $21^{\text {st }}$ Century. Current Plant Science and Biotechnology in Agriculture, vol 36. Springer, Dordrecht, https://doi.org/10.1007/978-94-011-4661-6_148

Kubota, S. and Yoneda, K. (1993). Effect of light intensity preceding day-night temperatures on the sensitivity of Phalaenopsis to flower (Japanese). Journal of Japanese Society of Horticultural Science, 62(3): 595- 600, https:// doi.org/10.2503/jjshs.62.595

Kwapata, M.B., Kalengamaliro, F., Bakuwa, J. and Manyela, S. (1999). In-vitro rooting and axillary shoots proliferation of (del.) of Faidherbia albida a. Chev. Under varying levels of plant growth regulators. African Journal of Crop Science, 7(4): 303-311, http://dx.doi.org/10.4314/acsj.v7i4.27723

Lopez-Figueroa F. and Neil F. X. (1989). Red-light and blue-light photoreceptors controlling chlorophyll a synthesis in the red alga Phorphyra umblicalis and in the alga Ulva rigida. Physiologia Planterum, 76(3): 391-397, https:// doi.org/10.1111/j.1399-3054.1989.tb06209.x

Miler, N. and Zalewska, M. (2006). The influence of light colour on micropropagation of chrysanthemum. Acta Horticulturae, 725(1): 347-350.

Miyashita, K., Tanakamaru, S., Maitani, T. and Kimura, K. (2005). Recovery responses of photosynthesis, transpiration, and stomatal conductance in kidney bean following drought stress. Environmental and Experimental Botany, 53: 205-214, https://doi.org/10.1016/j.envexpbot.2004.03.015

Moeinil, M.J., Armin, M., Asgharipour, M.R. and Yazdi, S.K. (2011). Effects of different plant growth regulators and potting mixes on micro-propagation and mini-tuberization of potato plantlets. Advanced Environmental Biology, 5(4): 631-638, http://scinet.dost.gov.ph/union/Downloads/631638_225057.pdf

Murashige,T. and Skoog, F. (1962). A revised medium for rapid growth and bio assays with tobacco tissue cultures, Physiologia Plantarum, 15: 473-497, https://doi.org/10.1111/ j.1399-3054.1962.tb08052.x

Nhut, D.T., Takamura, T., Watanabe, H., Okamoto, K. and Tanaka, M. (2003). Responses of strawberry plantlets cultured in vitro under superbright red and blue light emitting diods (LEDs). Plant Cell, Tissue and Organ Culture, 73:43-52, https://doi.org/10.1023/A:1022638508007

Standaet de Metsenaere, R.E.A. (1991). Economic Consideration. In: Debergh Pc and Zimmerman RH (Ed) Micropropagation (131-140) Kluwer Academic Publishers, Dordrecht, The Netherlands, https://link. springer.com/book/10.1007\% 2F978-94-009-2075-0

Silva, N.C.B., Macedo A.F., Lage C.L.S., Esquibel M.A. and Sato A. (2005). Developmental effects of additional ultra-violet a radiation, growth regulators and tyrosine in Alternanthera brasiliana (L.) Kuntze cultured in vitro. Brazilian Archives of Biotechnology, 48(5): 779-786, http://dx.doi.org/10.1590/ S1516-89132005000600014

Simko, I. (1994). Sucrose application causes hormonal changes associated with potato tuber induction. Journal of Plant Growth Regulation, 13: 73-77, https://doi.org/10.1007/ BF00210950

Theraja, B.L. and Theraja, A.K. (2005). A Text of Book of Electrical Technology. S. Chand \& Company Ltd. Volume 1, pp. 880, https://archive.org/details/a-textbook-of-electrical technology-volume-i-basic-electrical-engineering-b-l-theraja

Estrada, R., Tovar, P. \& Dodds, J.H. (1986). Induction of in vitro tubers in a broad range of potato genotypes. Plant Cell, Tissue and Organ Culture, 7(1):3-10, https://doi.org/ 10.1007/BF00043915

Tugrul, S. and Samanci, B. (2001). Factors affecting tuber formation in potato (Solanum tuberosum L.). Potato Abstract, 26: 86 .

Wang, P.J. and Hu, C.Y. (1985). Potato tissue culture and its applications in agriculture. In: Li, P.H. (ed.). Potato Physiology. Academic Press, Incorporation., London. pp. 503-577.

Zobayed, S.M.A., Armstrong, J. and Armstrong, W. (2001). Leaf anatomy of in vitro tobacco and cauliflower plantlets as affected by different types of ventilation. Plant Science, 161(3): 537-548, https://doi.org/10.1016/S0168-9452(01)00438-1 